\title{
Growth and Performance of Baby Spinach (Spinacia oleracea L.) Grown under Different Organic Fertilizers
}

\author{
C. Parwada $\mathbb{D},^{1,2}$ V. Chigiya $\mathbb{D},{ }^{1,3}$ W. Ngezimana $\mathbb{D}^{1},{ }^{1}$ and J. Chipomho ${ }^{1}$ \\ ${ }^{1}$ Marondera University of Agricultural Sciences and Technology, Department of Horticulture, P.O. Box 35, \\ Marondera, Zimbabwe \\ ${ }^{2}$ Faculty of Agricultural Sciences, Department of Horticulture, Women's University in Africa, P.O. Box 1175, \\ Marondera, Zimbabwe \\ ${ }^{3}$ Seke Teachers College, Mangwende Road 16120 P.O. Box Sk 41, Chitungwiza, Zimbabwe
}

Correspondence should be addressed to C. Parwada; cparwada@gmail.com

Received 26 September 2020; Revised 25 November 2020; Accepted 3 December 2020; Published 14 December 2020

Academic Editor: Allen Barker

Copyright (c) 2020 C. Parwada et al. This is an open access article distributed under the Creative Commons Attribution License, which permits unrestricted use, distribution, and reproduction in any medium, provided the original work is properly cited.

Spinacia oleracea L. (baby spinach) is a relatively new leaf vegetable crop in Zimbabwe, so the agronomic performance is unknown. A 3-year field experiment was done at the Seke Teachers College research farm, Zimbabwe. The research evaluated the response of baby spinach to different types of organic manure sources, days after fertilizer application (DAS), and growing season. A $3 \times 2$ factorial in a completely randomized block design (CRBD) with three replicates was used. Baby spinach cultivar, Dash, was grown on three organic manures (goat applied at $14.894 \mathrm{tha}^{-1}$, cattle at $17.789 \mathrm{t} \mathrm{ha}^{-1}$, and poultry at $13.807 \mathrm{t} \mathrm{ha}^{-1}$ ) in winter 2018 , 2019 , and 2020 . Compound D $(7 \% \mathrm{~N}, 14 \% \mathrm{P}$, and $7 \% \mathrm{~K})$ at $300 \mathrm{~kg} \mathrm{ha}^{-1}$ was included as a control. Crop growth rate, leaf area index, leaf area ratio, net assimilation rate, total dry matter production, and harvest index were measured on 7-day intervals from 14 to 35 days after transplanting. Analysis of variance (ANOVA) to compare the effects of the treatments on the baby spinach growth parameters was done. Significant $(p<0.05)$ interactions on the type of organic manure $\times$ DAS $\times$ growing season were observed on all the measured response variables. There were varied effects of organic manures on growth performance at 14 to $28 \mathrm{DAS}$ where poultry manure had higher growth performance compared to cattle and goat manure. Generally, there was a significant $(\mathrm{p}<0.05)$ gradual increase in growth from 14 to 35 DAS on the organic manures and a decline from day 28 to 35 DAS under compound D. Low quality (large $\mathrm{C} / \mathrm{N})$ cattle and goat manure had lower effects than high quality $($ small $\mathrm{C} / \mathrm{N})$ poultry manure at early growth stages of the baby spinach. Unlike compound D, organic manure continuously supplied adequate nutrients throughout the life cycle (35 DAS) of the baby spinach.

\section{Introduction}

Spinacia oleracea L. (baby spinach) is a relatively new leaf vegetable in Zimbabwe belonging to the Amaranthaceae family. The crop is high in human nutrients and has relatively high levels of bioactive compounds like vitamins A and $\mathrm{C}$ and minerals [1]. The baby spinach is a quick maturing, cool season crop that grows well under the temperature of $5^{\circ}$ to $30^{\circ} \mathrm{C}$, though growth is accelerated at $15^{\circ}$ to $18^{\circ} \mathrm{C}[2]$. The baby spinach is a short season crop that is harvested when still young and has relatively low nutrient uptake. The crop grows slowly in the early stages and accelerates during the final 21 days before harvest [2]. The baby spinach leaves are relatively small $(7.5-10 \mathrm{~cm})$ and can be harvested up to 35 days after planting. The nitrogen $(\mathrm{N})$ requirement for the baby spinach varies from 21 to $45 \mathrm{~kg}$ $\mathrm{ha}^{-1}, 63$ to $138 \mathrm{~kg} \mathrm{ha}^{-1} \mathrm{P}$, and 22 to $45 \mathrm{~kg} \mathrm{ha}^{-1} \mathrm{~K}$ [3]. The crop adapts well to a variety of soils but favours the sandy loam [2]. It requires slightly acid to slightly basic soil ( $\mathrm{pH}$ 6-7.5) but can tolerate soils with a $\mathrm{pH}$ of above 8.0 [4].

Organic fertilizers, such as farmyard manure, poultry and goat manure, and biofertilizers, can be substitutes for the inorganic fertilizers in the production of baby spinach [5]. Organic fertilizers have associated cobenefits such as improving the soil aggregation thereby modifying soil physical properties, e.g., water holding capacity and 
aeration. Nevertheless, the effect of organic manure on soil and crop productivity varies with its quality. The quality of organic manure refers to its chemical composition in relation to nutrient content, which was shown to strongly influence the rate of decomposition [6]. The quality of manure influences the rate of mineralisation and hence the availability of $\mathrm{N}$ and other nutrients to the plants. Much research on organic matter quality has linked the quality of manure to its mineralisation $[6,7]$. Generally, high quality (small $\mathrm{C} / \mathrm{N}$ ) organic manure, e.g., poultry manure, has a higher rate of mineralisation than low quality (large $\mathrm{C} / \mathrm{N}$ ) like cattle manure. It is, therefore, imperative to know the type of organic manure leading to high crop growth and performance for any particular soil type.

The organic manure can also affect the quality of the baby spinach leaves. The quality of baby spinach leaves was noted to be directly influenced by the soil nutrient content [1]. High levels of readily available $\mathrm{N}$ were shown to reduce leaf quality of the baby spinach by increasing the leaf nitrate concentrations $[8,9]$. However, low available $\mathrm{N}$ resulted in stunted leaf leading to poor physiochemical quality of the crop. The application of inorganic fertilizers was positively correlated with high leaf nitrate concentrations in the early growth stages of the baby spinach [9]. This was due to the quick-release effects of the inorganic fertilizers. Leaves with low-moderate nitrate concentrations were recorded under slow-release (organic) fertilizers during spinach growth [5]. Nevertheless, information on the effects of different types of organic manure on the baby spinach leaf quality is unclear.

Besides, the organic manure quality and soil properties, e.g., texture, also influence the rate of mineralisation. However, there is little information on the effects of organic manure type and soil type on the productivity of baby spinach. In Zimbabwe, many of the resource-constrained farmers are located on inherently infertile soils and rely on organic manure for crop production [10]. At least $70 \%$ of the soils in Zimbabwe are classified as arenosols (sandy) which are naturally infertile, acidic, poorly aggregated, and highly leached and result in low crop productivity [11]. The effect of applying organic manure on the productivity of arenosols is currently general regardless of the fact that different organic manure types have varying effects on the soil and crop responses. It was, therefore, imperative to evaluate the effects of different types of organic manure on crop growth and performance in arenosols. Therefore, the objective of this study was to determine the growth response of baby spinach to different types of organic manure. We hypothesised that the growth of the baby spinach was influenced by the quality of organic manure at any given growth stage.

\section{Materials and Methods}

2.1. Study Site. The study was carried out during the winters (June-August) in 2018, 2019, and 2020 at Seke Teachers College (STC) experimental fields, Zimbabwe $\left(18^{\circ} 01^{\prime} 98^{\prime \prime} \mathrm{S}\right.$ and $\left.31^{\circ} 06^{\prime} 79^{\prime \prime} \mathrm{E}\right)$. The STC is situated about $26 \mathrm{~km}$ south of Harare and has the average maximum and minimum temperatures of $25.3^{\circ} \mathrm{C}$ and $12.2^{\circ} \mathrm{C}$, respectively. The STC lies in the natural farming region (NR) IIb of Zimbabwe. The area is characterised by a unimodal wet summer season receiving rainfall of $850 \mathrm{~mm} \mathrm{yr}^{-1}$ that falls between October and April. The cold dry winter season is from May to July. The soils at the STC research farm are classified as arenosols according to the IUSS Working Group WRB [12]. The soil nutrient status of the research farm was analysed at the beginning of the experiment (Table 1).

2.2. Experimental Design. A $3 \times 2$ factorial in a completely randomized block design (CRBD) with three replicates was used in the experiment. The slope was the blocking factor. The plots were $1.2 \times 1.0 \mathrm{~m}$ with 3 rows in each plot and a $50 \mathrm{~cm}$ space between plots. A planting density of 166667 plants ha ${ }^{-1}$ was used.

2.3. Crop Establishment and Agronomic Practices. Baby spinach cultivar, Dash, was grown in winter (June to August) in 2018, 2019, and 2020. Goat, poultry, and cattle manure were used in this study. The organic manures were decomposed for 14 weeks before use to achieve partial decomposition. Compound D (7\% N, 14\% P, 7\% K) also used a control fertilizer. Both the compound $\mathrm{D}$ and the organic manure were applied at the transplanting stage. The compound $\mathrm{D}$ was applied using the blanket recommended rate ( $300 \mathrm{~kg} \mathrm{ha}^{-1}$ i.e., $21 \mathrm{~kg} \mathrm{~N} \mathrm{ha}^{-1}$ ) in the study area. The organic manure application rates were also applied according to the recommended blanket $\mathrm{N}$. Hence, the quantities of organic manure applied were determined according to the amount of extractable $\mathrm{NO}_{2} / \mathrm{NO}_{3}\left(\mathrm{mg} \mathrm{kg}^{-1}\right)$ in the manure. Goat manure was applied at $14.894 \mathrm{t} \mathrm{ha}^{-1}$, cattle manure at $17.789 \mathrm{t} \mathrm{ha}^{-1}$, and the poultry manure at $13.807 \mathrm{t} \mathrm{ha}$ (Table 2). Soil moisture was uniformly maintained at field capacity in all the plots.

2.4. Soil and Organic Manure Analysis. Five soil samples were taken to a depth of $0-200 \mathrm{~mm}$ using a soil auger in June 2018. The sampling was done per plot and then mixed to make a composite soil sample before analyses. The goat, poultry, and cattle manures were sourced from the STC livestock farm section and sun-dried for a week to homogenise the moisture content. After the drying, a $500 \mathrm{~g}$ of manure was randomly taken for analysis, and the bulky was stored for use.

Soil $\mathrm{pH}$ and electrical conductivities (ECs) were measured in a soil-water suspension (ratio of $1: 5$ ) using a TPS meter as described by Okalebo et al. [13]. The soils were initially analysed for primary particle size distribution by the hydrometer method as described by Okalebo et al. [13]. Total carbon (C) and nitrogen (N) determination, Olsen extractable $\mathrm{P}$, and exchangeable ammonium and nitrate and nitrite in both the organic manures (poultry, goat, and cattle) and soil were analysed as described by Parwada and Van Tol [14].

2.5. Data Collection. Data was collected at a 7-day interval starting from 7 to 35 days after transplanting. Harvest index (HI), crop growth rate (CGR), total dry matter production 
TABLE 1: Response variables measured in the experiment.

\begin{tabular}{|c|c|c|}
\hline Response variables & Acronym used & Equation used \\
\hline Harvest index & $\mathrm{HI}$ & $\mathrm{HI}=\left(\right.$ Fresh weight of harvestable leaves $\left(\mathrm{t} \mathrm{ha}^{-1}\right) /$ Total biological yield $\left.\left(\mathrm{t} \mathrm{ha}^{-1}\right)\right) \times 100$ \\
\hline Crop growth rate & CGR & $C G R=\left(W_{2}-W_{1}\right) / \rho\left(t_{2}-t_{1}\right) g m^{-2}$ day $^{-1}$ \\
\hline Total dry matter production & TDMP & TDMP $=$ TDMW per plot $(\mathrm{t}) /$ Area per plot $(h a) \mathrm{tha}^{-1}$ \\
\hline Leaf area index & LAI & LAI $=$ Total leaf area of plant/Ground area occupied by the plant \\
\hline Leaf area ratio & LAR & $\mathrm{LAR}=$ Total leaf area of plant/Plant dry weight $\mathrm{cm}^{-2} \mathrm{~g}^{-1}$ \\
\hline Net assimilation rate & NAR & $\operatorname{NAR}=\left(\left(W_{2}-W_{1}\right) /\left(t_{2}-t_{1}\right)\right) \times\left(\left(\log _{e} L_{2}-\log _{e} L_{1}\right) / L_{2}-L_{1}\right) g g^{-1}$ day $^{-1}$ \\
\hline
\end{tabular}

$\mathrm{W}_{1}$ and $\mathrm{W}_{2}$ were the whole plant dry weights at time $\mathrm{t}_{1}-\mathrm{t}_{2}$, respectively, and $\rho$ is the ground area of which $\mathrm{W}_{1}$ and $\mathrm{W}_{2}$ were recorded. $L_{1}$ and $L_{2}$ were leaf weights at $t_{1}$ and $t_{2}$ times, respectively.

TABLE 2: The initial chemical properties of the soil at the Seke Teachers College (STC), experimental field, and organic manures used in the study.

\begin{tabular}{|c|c|c|c|c|}
\hline \multirow[b]{2}{*}{ Parameter } & \multicolumn{4}{|c|}{ Organic manure } \\
\hline & Soil & Goat & Cattle & Poultry \\
\hline Sand (\%) & $75 \pm 5.1$ & & & \\
\hline Silt (\%) & $20 \pm 5.1$ & & & \\
\hline Clay (\%) & $5 \pm 5.1$ & & & \\
\hline $\mathrm{pH}\left(\mathrm{H}_{2} \mathrm{O}\right)$ & $4.5 \pm 0.1$ & $6.8 \pm 0.5$ & $7.15 \pm 0.3$ & $6.6 \pm 0.3$ \\
\hline $\mathrm{EC}\left(\mathrm{dSm}^{-1}\right)$ & $3.1 \pm 0.02$ & $5.6 \pm 0.2$ & $5.85 \pm 0.1$ & $5.7 \pm 2.1$ \\
\hline $\mathrm{CEC}\left(\mathrm{cmol}_{(+)} \mathrm{kg}^{-1}\right)$ & $71.0 \pm 0.1$ & $312.0 \pm 0.6$ & $216.2 \pm 0.7$ & $329.0 \pm 1.3$ \\
\hline Total C (\%) & $0.8 \pm 0.03$ & $22.0 \pm 0.7$ & $29.7 \pm 0.2$ & $20.1 \pm 1.4$ \\
\hline Total N (\%) & $0.9 \pm 0.04$ & $5.18 \pm 0.1$ & $3.10 \pm 0.1$ & $6.3 \pm 1.1$ \\
\hline $\mathrm{C}: \mathrm{N}$ ratio & $0.5 \pm 0.01$ & $4.2 \pm 1.2$ & $9.6 \pm 0.5$ & $3.2 \pm 0.8$ \\
\hline Olsen extractable $\mathrm{P}\left(\mathrm{mg} \mathrm{kg}^{-1}\right)$ & $401.0 \pm 2.11$ & $1300.0 \pm 5.3$ & $1210.6 \pm 6.5$ & $1320 \pm 4.1$ \\
\hline Extractable $\mathrm{NO}_{2} / \mathrm{NO}_{3}\left(\mathrm{mg} \mathrm{kg}^{-1}\right)$ & $33.2 \pm 1.03$ & $1410.0 \pm 7.4$ & $1180.5 \pm 6.7$ & $1521 \pm 5.1$ \\
\hline Extractable $\mathrm{NH}_{4}\left(\mathrm{mg} \mathrm{kg}^{-1}\right)$ & $111.4 \pm 0.9$ & $421.1 \pm 3.7$ & $391.6 \pm 1.6$ & $410.2 \pm 2.1$ \\
\hline $\mathrm{Ca}\left(\mathrm{mg} \mathrm{kg}^{-1}\right)$ & $0.2 \pm 0.02$ & $24.2 \pm 3.2$ & $25.3 \pm 2.2$ & $30.1 \pm 3.1$ \\
\hline $\mathrm{K}\left(\mathrm{mg} \mathrm{kg}^{-1}\right)$ & $7.3 \pm 0.8$ & $3.1 \pm 0.6$ & $2.8 \pm 0.4$ & $3.5 \pm 0.8$ \\
\hline $\operatorname{Mg}\left(\mathrm{mg} \mathrm{kg}^{-1}\right)$ & $30.6 \pm 1.4$ & $14.7 \pm 2.2$ & $12.2 \pm 1.5$ & $13.1 \pm 0.7$ \\
\hline $\mathrm{Na}\left(\mathrm{mg} \mathrm{kg}^{-1}\right)$ & $0.54 \pm 0.06$ & $1.4 \pm 0.3$ & $1.7 \pm 0.1$ & $1.1 \pm 0.6$ \\
\hline $\mathrm{Cu}\left(\mathrm{mg} \mathrm{kg}^{-1}\right)$ & $241.2 \pm 40.1$ & $344.1 \pm 36.2$ & $342.2 \pm 46.5$ & $333.1 \pm 36.2$ \\
\hline $\mathrm{Zn}\left(\mathrm{mg} \mathrm{kg}^{-1}\right)$ & $100.5 \pm 8.7$ & $566.3 \pm 11.5$ & $537.3 \pm 0.4$ & $589.2 \pm 0.6$ \\
\hline
\end{tabular}

(1) EC, electrical conductivity; CEC, cation exchange capacity. (2) Data are means \pm standard error of the means for three replicates.

(TDMP), leaf area index (LAI), leaf area ratio (LAR), and net assimilation rate (NAR) were measured as shown in Table 1. Data was collected from three randomly selected plants for the destructive growth analysis parameters (HI, CGR, TDMP, LAR, and NAR). Five plants per plot were randomly selected and used for the nondestructive growth analysis parameters (LAI).

2.6. Data Analysis. The observations were independent of each other; data followed a normal distribution and homoscedasticity, and thus, a three-factor analysis of variance (ANOVA) was run to compare growth parameters of the baby spinach under different organic manures, days after manure application, and growing seasons. All data were analysed using JMP version 11.0.0 statistical software.

\section{Results}

The soil was high (75\%) in sand content and inherently low in nutrient content compared to the organic manures (Table 2). The soil had an acidic pH (4.5) with the lowest cation exchange capacity and values of $71 \mathrm{cmol}_{(+)} \mathrm{kg}^{-1}$ and
$3.1 \mathrm{dSm}^{-1}$, respectively. In addition, the soil had lower total $\mathrm{C}, \mathrm{N}, \mathrm{P}$, and $\mathrm{Ca}$ which were consistent with the lower cation exchange capacity (CEC) compared to the organic manures. Nevertheless, the soil had higher quantities of $\mathrm{K}$ and $\mathrm{Mg}$ compared to the organic manure sources. Poultry manure had the lowest (3.2) $\mathrm{C} / \mathrm{N}$ ratio among the types of organic manure used (Table 2).

The interaction effect of manure $x$ days after fertilizer application $\times$ growing season was significant $(p<0.05)$ for all the growth parameters of the baby spinach (Table 3 ). The effect of the growing season $(S)$ was not significant $(\mathrm{p}<0.05)$ on all the measured response variables (Table 3 ).

All the measured growth parameters of the baby spinach were significantly $(\mathrm{p}<0.05)$ lower on the organic manures than compound D at days 14 and 21 (Table 4). However, the growth parameter started to be gradually lower under compound D than organic manure from day 28 up to day 35 after transplanting (Table 4).

The harvest index was the highest (0.88) and lowest (0.08) on poultry and cattle manure at days 14 and 35 of application, respectively (Table 4). A similar trend was observed on TDMP, LAI, LAR, and NAR. The highest $(68.1 \mathrm{t}$ $\mathrm{ha}^{-1}$ ) and lowest $\left(26.2 \mathrm{t} \mathrm{ha}^{-1}\right)$ TDMP were recorded on 
TABLE 3: The ANOVA summary for the mean square values of the baby spinach growth parameters and yield during the three years.

\begin{tabular}{lccccccc}
\hline Source of variation & & HI & CGR & TDMP & LAI & LAR & NAR \\
\hline \multirow{2}{*}{ Manure $(M)$} & $\mathrm{F}_{3,12}$ & 6.693 & 5.995 & 3.476 & 2.134 & 4.714 & 1.123 \\
& $\mathrm{P}$ & 0.003 & 0.004 & 0.001 & 0.002 & $<0.001$ & $<0.001$ \\
\hline \multirow{2}{*}{ Day $(D)$} & $\mathrm{F}_{3,34}$ & 4.136 & 2.415 & 1.324 & 1.562 & 2.174 & 2.653 \\
& $\mathrm{P}$ & $<0.001$ & 0002 & $<0.001$ & 0.001 & 0.022 & $<0.001$ \\
\hline \multirow{2}{*}{$M \times D$} & $\mathrm{~F}_{6,105}$ & 42.313 & 4.103 & 5.002 & 3.148 & 1.112 & 3.214 \\
& $\mathrm{P}$ & $<0.001$ & 0004 & $<0.001$ & 0.003 & 0.035 & $<0.001$ \\
\hline \multirow{2}{*}{ Season $(S)$} & $\mathrm{F}_{2,6}$ & 2.130 & 1.006 & 3.172 & 3.115 & 1.102 & 2.103 \\
& $\mathrm{P}$ & $\mathrm{Ns}$ & $\mathrm{Ns}$ & $\mathrm{Ns}$ & $\mathrm{Ns}$ & $\mathrm{Ns}$ \\
\multirow{2}{*}{$\mathrm{M} \times \mathrm{D} \times S$} & $\mathrm{~F}_{12,130}$ & 70.183 & 2.104 & 3.172 & 3.151 & 1.732 & 3.514 \\
& $\mathrm{P}$ & $<0.001$ & 0003 & $<0.001$ & 0.004 & 0.015 & $<0.001$ \\
\hline
\end{tabular}

Note. HI, CGR, TDMP, LAI, LAR, and NAR are the harvest index, crop growth rate, total dry matter production, leaf area index, leaf area ratio, and net assimilation rate, respectively.

poultry and cattle manure at days 35 and 14 after application, respectively. The leaf area index was the highest (12.1) on poultry manure at day 35 and the lowest (4.41) on cattle manure at day 14 of application (Table 4 ). The LAR and NAR were also the highest $\left(4.31 \mathrm{~cm}^{-1} \mathrm{~g}^{-1}\right.$ and $0.9 \mathrm{~g} \mathrm{~g}^{-1}$ day $^{-1}$, respectively) on poultry manure at day 35 after application. The lowest $\left(0.81 \mathrm{~cm}^{-1} \mathrm{~g}^{-1}\right)$ LAR and $\left(0.04 \mathrm{~g} \mathrm{~g}^{-1} \mathrm{day}^{-1}\right)$ NAR were observed at day 14 after application on cattle manure (Table 4). The CGR was the highest $\left(181.4 \mathrm{~g} \mathrm{~m}^{-1} \mathrm{day}^{-1}\right)$ on poultry manure at day 35 and the lowest $\left(140.1 \mathrm{~g} \mathrm{~m}^{-1}\right.$ day $\left.^{-1}\right)$ on cattle manure at day 14 of application (Table 4).

The effects of the added fertilizers on baby spinach growth parameters were the highest at 14 and 21 days after application. For example, changes in the HI were the highest $(+311.1 \%)$ and lowest $(+147.6 \%)$ on goat and compound D, respectively (Table 4 ). The compound $\mathrm{D}$ had negative changes while poultry manure had the smallest positive changes in the LAI, CGR, LAR, NAR, TDMP, and HI among the organic manures starting from 28 to 35 days of application (Table 4).

\section{Discussion}

The effects of type of organic manure on the baby spinach growth parameters varied with time after application. The compound D resulted in the highest growth of baby spinach at days 14 and 21 after application and, thereafter, gradually declined. The organic manure (cattle and goat) had a steady increasing effect on the growth of the baby spinach from day 14 up to day 35 of application (Table 4 ). The poultry manure effect on the growth parameters was significantly $(\mathrm{p}<0.05)$ the same as compound D from day 14 to day 28 after application. The variations in growth parameters noted among the types of organic manure could be explained by variations in the quality of the organic manure. The poultry manure was shown to have qualities that enhanced baby spinach growth more than the cattle and goat manure (Table 4 ).

In this study, we applied the same quantities of $\mathrm{N}(21 \mathrm{~kg}$ $\mathrm{N} \mathrm{ha}^{-1}$ ) from both the compound $\mathrm{D}$ (inorganic) and organic manure, suggesting that the growth response of the baby spinach was due to differences in the rates of mineralisation. Leaf area index increased significantly $(\mathrm{p}<0.05)$ in all types of organic manure at later stages of the baby spinach growth (days 28 and 35) (Table 4). The results were similar also to those reported by Ogunlela et al. [15] who noted an increase in LAI value on okra under different chemical fertilizer application rates. The LAI value may be attributed towards the stimulating effect of rate of nutrient release of a fertilizer which improved the availability of nutrients and their uptake by crop plants [16] along with a greater amount of light interception by the crop plants which have contributed towards the observed variations on baby spinach growth rate under the different organic fertilizers [3].

The LAI value showed a decreasing trend in all the treatments at the initial stage (day 14) of development but gradually increased at the time of crop maturity except a decrease noted under compound D at 28 and 35 days after application (Table 4). Therefore, the LAI was increasing with an increase of time after transplanting due to newly emerged leaves. This could be due to stimulating the slow-release effect of the organic manure unlike in compound D where nutrients were quickly released in the initial growth stages. With time, the $\mathrm{N}$ quantities in compound $\mathrm{D}$ were declining and resulted in a decrease in the baby spinach growth rate. Nevertheless, all the organic nutrient sources were shown to enhance the baby spinach growth rate at later stages (from day 21 up to day 35 after application); this could be due to the slow-release effects of nutrients which gradually improved the nutrient availability and their uptake with time. These results are consistent with observations by Ogunlela et al. [15] who noted a significant influence of organic fertilizers with time on the LAI value of sunflower plants.

The LAR shows how a system is efficient in growth by reflecting the ratio of photosynthesizing to respiring material within a plant. In this study, there were significant variations on the LAR under different organic sources at 14 and 21 days after application; this reflected significant variations in the nutrient release by the fertilizers. The different rates at which nutrients were mineralised from the different types of organic manure affected the amount of available plant nutrients in the soil. The poultry manure was highly mineralised at the 14 and 21 days after application enhancing anabolism of sugars resulting in an increase in dry matter production within the baby spinach tissues. During the same 
TABLE 4: Effects of type of organic source $\times$ days after fertilizer application $\times$ growing season on the baby spinach the growth parameters.

\begin{tabular}{|c|c|c|c|c|c|c|c|c|c|c|c|c|c|c|c|c|c|c|c|}
\hline & & \multicolumn{3}{|c|}{ H1 } & \multicolumn{3}{|c|}{ CGR } & \multicolumn{3}{|c|}{ TDMP } & \multicolumn{3}{|c|}{ LAI } & \multicolumn{3}{|c|}{ LAR } & \multicolumn{3}{|c|}{ NAR } \\
\hline & Year & 1 & 2 & 3 & 1 & 2 & 3 & 1 & 2 & 3 & 1 & 2 & 3 & 1 & 2 & 3 & 1 & 2 & 3 \\
\hline \multirow{4}{*}{ Day 14} & Cattle & 0.08 & 0.10 & 0.09 & 155.8 & 156.2 & 156.3 & 26.2 & 26.4 & 25.9 & 4.99 & & & 0.81 & 0.82 & 0.81 & 0.05 & & 0.04 \\
\hline & Goat & 0.09 & 0.08 & 0.10 & 168.2 & 168.7 & 167.0 & 29.1 & 28.9 & 29.0 & 5.18 & 5.19 & & 0.90 & 0.89 & 0.88 & 0.05 & .04 & 0.03 \\
\hline & Poultry & 0.19 & 0.18 & 0.19 & 178.2 & 177.9 & 177.8 & 32.4 & 31.5 & 31.1 & 7.57 & 7.47 & 7.58 & 1.08 & 1.10 & 1.09 & 0.07 & .07 & 0.06 \\
\hline & Comp & 0.21 & 0.21 & 0.20 & 181.4 & 180.1 & 179.3 & 34.2 & 33.1 & 34.3 & 8.38 & 8.39 & 8.40 & 1.78 & 1.77 & 1.78 & 0.08 & 0.08 & 0.08 \\
\hline \multirow{4}{*}{ Day 21} & & 36 & 34 & 34 & 0.2 & 512 & & & & 34. & 5.77 & 5.7 & & 1.39 & 1.37 & 1.38 & 0.06 & .06 & 0.06 \\
\hline & & .38 & 0.37 & 0.37 & 165.2 & 165.4 & .9 & 37.3 & 37.3 & 37.6 & 7.10 & 7.1 & 7. & 1.43 & 1.44 & 41 & 0.06 & 0.07 & 0.06 \\
\hline & Poultry & 0.49 & 0.48 & 0.49 & 162.2 & 161.0 & 161 & 48.2 & 49.1 & 48.4 & 8.82 & 8.6 & 8. & 2.11 & 2.13 & 2.10 & 0.08 & 0.09 & 0.08 \\
\hline & Com & 0.52 & .52 & 0.53 & 170.1 & 169.3 & & 54.1 & 55.0 & 54.3 & 9.17 & .14 & & 2.44 & 2.40 & 39 & .09 & .09 & 0.09 \\
\hline \multirow{4}{*}{ Day 28} & & 0.59 & 0.58 & 0.61 & 158.1 & 159.4 & 158.7 & 47.4 & 47.6 & 46.5 & 6.57 & 6.58 & 6. & 1.91 & 1.90 & 1.91 & 0.07 & .07 & 0.08 \\
\hline & & 0.57 & 0.56 & 0.59 & 166.5 & 168.7 & 167.0 & 48.2 & 48.9 & 48.0 & 7.78 & 7.69 & 7. & 1.80 & 1.79 & 1.81 & 0.07 & 0.07 & 0.07 \\
\hline & Poultry & 0.75 & 0.74 & 0.74 & & & & 59.8 & & & 8.17 & 8.3 & & 1.88 & 1.90 & 1.89 & 0.07 & 0.09 & 0.08 \\
\hline & $\mathrm{Com}$ & 0.72 & 0.71 & 0.70 & 165.4 & 162.2 & 163.1 & 60.6 & 63.4 & 62.1 & 9.81 & 9.93 & 9.60 & 2.61 & 2.67 & 2.64 & 0.06 & 0.06 & 0.06 \\
\hline \multirow{4}{*}{ Day 35} & & & & & & & & & & & & & & & & & 0.08 & 0.07 & 0.08 \\
\hline & Goat & 0.68 & 0.66 & 0.67 & 144.0 & 142.8 & 143.7 & 59.0 & 60.2 & 59.8 & 11.2 & 11.3 & 11.4 & 3.81 & 3.94 & 3.81 & 0.07 & 0.07 & 0.80 \\
\hline & Poultry & 0.88 & 0.89 & 0.89 & 151.2 & 151.7 & 152.4 & 68.1 & 69.4 & 68.2 & 12.1 & 12.0 & 12.2 & 4.31 & 4.41 & 4.10 & 0.09 & 0.09 & 0.08 \\
\hline & Comp. D & 0.62 & 0.64 & 0.63 & 161.3 & 160.4 & 161.2 & 56.4 & 57.1 & 57.4 & 9.4 & 9.5 & 9.6 & 2.92 & 2.82 & 2.90 & 0.05 & 0.04 & 0.04 \\
\hline \multicolumn{2}{|c|}{$\mathrm{LSD}_{0.05}(\mathrm{M} \times \mathrm{D} \times \mathrm{S})$} & & 0.14 & & & 9.14 & & & 7.12 & & & 3.20 & & & 0.90 & & & 0.003 & \\
\hline
\end{tabular}

Year $1=2018$, Year $2=2019$, Year $3=2020, M=$ organic manure, $D=$ days after organic application, $S=$ growing season, and Comp. $\mathrm{D}=$ compound $\mathrm{D}$. HI, CGR, TDMP, LAI, LAR, and NAR are the harvest index, crop growth rate, total dry matter production, leaf area index, leaf area ratio, and net assimilation rate, respectively.

growth phase, catabolism of the sugars could have been increased in order to compensate for the energy consumed during the active pumping of nutrients into the plant system.

The crop growth rate is a simple and important index of agricultural productivity on the rate of dry matter production. Previous researches have shown a significant positive correlation between crop growth rate and the LAI where optimum CGR is achieved when the LAI is large to intercept $95 \%$ of the sun's light $[17,18]$. Greater light interception stimulates CGR which led to increased TDMP and LAI with time after fertilizer application (Table 4). Higher LAI values resulted in higher light interception which further enhanced the CGR and thus resulted in higher HI values at later growth stages of the baby spinach under cattle, goat, and poultry manure. In this study, our findings were similar to the earlier findings by Ariyo et al. [19].

Generally, the HI refers to the \% ratio of economic and biological yield of a crop. Our results showed considerable variations in the HI value among the fertilizers. This could be due to varying rates of nutrient release by the fertilizers leading to varied rates of translocation of assimilates towards leaf development, leading to variability in fresh leaf yield and $\mathrm{HI}$ value among the organic manure sources [18]. The LAR is the ratio of leaf area and total plant weight and is a product of the morphological component (specific leaf area), or in a broader sense, it is the ratio of leaf area and leaf weight and the leaf weight ratio, indicating the fraction of total plant weight allocated to the leaves. The LAR is important in explaining differences in the relative growth rate; hence, this factor is imperative in plant growth analysis. Generally, the allocation of dry matter to leaves is higher at the fastgrowing phase of a plant. In this study, the LAR was gradually increasing from 14 to 35 days of organic manure application and started to decline from day 28 on compound D (Table 4).

The net assimilation rate (NAR) was significantly $(\mathrm{p}<0.05)$ affected by the source of fertilizer (Table 4$)$. Net assimilation rate is related to photosynthetic activities of the leaf, i.e., rate of increase in dry weight of the whole plant per unit leaf area. The results showed significant variations of NAR due to types of organic manure at days 14,21 , and 28 of application. The NAR on compound D was significantly lower than in all the organic manures at the later growth stages of baby spinach, and this could have been caused by the accumulation of siliquae that cause differential rate in supplying photoassimilate towards the vegetative growth of the baby spinach. For high quality, baby spinach leaves are harvested while they are still tender and usually the maturity stage (siliquae formation stage) begins at around 35 days after planting. At $>35$ days after planting, the rate of photosynthesis in the leaves could have decreased and siliquae and lignification increased so by lowering the leaf quality. Gonzales and Aban [20] and Hammad et al. [17] noted similar variations in the NAR due to the formation of siliquae in aging crops causing a differential rate of supply of photoassimilate towards the vegetative growth. However, in the current study, the siliquae were not quantified, so further researches to ascertain, characterise, and quantify the siliquae in baby spinach leaves are necessary. 


\section{Conclusion and Recommendations}

The application of different organic manures had varied effects on LAI, CGR, LAR, NAR, TDMP, and HI of the baby spinach at 14 to 28 days of application. Poultry manure had significantly the highest influence on baby spinach growth in the early developmental stages (14 and 21 days after application). Relatively high $(\mathrm{C} / \mathrm{N})$ organic manure (cattle and goat manure) had lower effects than low $(\mathrm{C} / \mathrm{N})$ manure (poultry manure) at the early growth stages of baby spinach. Cattle and goat manure had a gradually increasing effect on the growth of the baby spinach from 14 to 35 days after application. The rate of mineralisation of different types of organic manure in the arenosols was reflected by crop growth rate and net assimilation rate which were in fact the gain in dry biomass of the plants. Results also showed a steadily increasing rate of mineralisation in cattle and goat manure which enhanced the LAI, CGR, LAR, NAR, TDMP, and $\mathrm{HI}$ of baby spinach leading to higher productivity.

\section{Data Availability}

The raw data used to support the findings of this study are available from the corresponding author upon request.

\section{Conflicts of Interest}

The authors declare that they have no conflicts of interest.

\section{Acknowledgments}

The research did not receive any specific funding but was performed as part of employment at the Marondera University of Agricultural Sciences and Technology, Zimbabwe. The authors gratefully acknowledge the Seke Teachers College, Department of Agricultural Education, for the resources to carry out this study at the College Farm.

\section{References}

[1] L. E. Nemadodzi, H. Araya, M. Nkomo, W. Ngezimana, and N. F. Mudau, "Nitrogen, phosphorus, and potassium effects on the physiology and biomass yield of baby spinach (Spinacia oleracea L.)," Journal of Plant Nutrition, vol. 40, no. 14, pp. 2033-2044, 2017.

[2] S. Bergquist, "Bioactive compounds in baby spinach (Spinacia oleracea L.). Effects of pre- and postharvest factors," $\mathrm{PhD}$ Thesis, Swedish University of Agricultural Sciences, Uppsala, Sweden, 2006.

[3] M. I. Jakhro, S. I. Shah, Z. M. Amanullah, Z. A. Rahujo, S. Ahmed, and M. A. Jakhro, "Growth and yield of spinach (Spinacia oleracia) under fluctuating levels of organic and inorganic fertilizers," International Journal of Development Research, vol. 7, pp. 11454-11460, 2017.

[4] V. Worthington, "Nutritional quality of organic versus conventional fruits, vegetables and grains," Journal of Alternative and Complentary Medicine, vol. 7, pp. 161-173, 2011.

[5] T. Ciesielczuk, C. Rosik-Dulewska, J. Poluszyńska, and I. Sławińska, "Acute toxicity of experimental fertilizers made of blood meal, spent coffee ground and biomass ash," Journal of Water and Land Development, vol. 34, no. 1, pp. 95-102, 2017.
[6] O. W. Heal, J. M. Anderson, and M. J. Swift, "Plant litter quality and decomposition: an historical overview," in Driven by Nature: Plant Litter Quality and Decomposition, G. Cadisch and K. E. Giller, Eds., pp. 3-30, CAB International, Wallingford, UK, 1997.

[7] I. Trinsoutrot, S. Recous, B. Bentz, M. Linères, D. Chèneby, and B. Nicolardot, "Biochemical quality of crop residues and carbon and nitrogen mineralization kinetics under nonlimiting nitrogen conditions," Soil Science Society of America Journal, vol. 64, no. 3, pp. 918-926, 2000.

[8] V. K. Dua, P. M. Govindakrishnan, and S. S. Lal, "Effect of FYM and n levels on spinach yield, N-use efficiency and soil fertility in potato-spinach sequence," Potato Journal, vol. 37, pp. 151-156, 2010.

[9] P. C. R. Fontes, P. R. G. Pereira, and R. M. Conde, "Critical chlorophyll, total nitrogen and nitrate nitrogen in leaves associated to maximum lettuce yield," Journal of Plant $\mathrm{Nu}$ trition, vol. 20, pp. 1061-1068, 2017.

[10] M. Wuta and P. Nyamugafata, "Management of cattle and goat manure in Wedza smallholder farming area, Zimbabwe," African Journal of Agricultural Research, vol. 7, pp. 3853-3859, 2012.

[11] K. Nyamapfene, Soils of Zimbabwe, Nehanda Publishers, Harare, Zimbabwe, 1991.

[12] IUSS Working Group WRB, World Reference Base for Soil Resources 2014, Update 2015, International Soil Classification System for Naming Soils and Creating Legends for Soil Maps, FAO, Rome, Italy, 2015.

[13] J. B. Okalebo, K. W. Gathua, and P. L. Woomer, Laboratory Methods of Soil and Plant Analysis: A Working Manual, Tropical Soil Biology and Fertility Programme, Nairobi, Kenya, 2000.

[14] C. Parwada and J. Van Tol, "Effects of litter quality on macroaggregates reformation and soil stability in different soil horizons," Environment, Development and Sustainability, vol. 21, pp. 1321-1339, 2018.

[15] V. Ogunlela, M. Masarirambi, and S. M. Makuza, "Effect of cattle manure application on pod yield and yield indices of okra (Abelmoschus esculentus L. Moench) in a semi-arid subtropical environment," Journal of Food Agriculture and Environment, vol. 3, no. 1, pp. 125-129, 2005.

[16] H. L. Xu, R. Wang, R. Y. Xu, M. A. U. Mridha, and S. Goyal, "Yield and quality of leafy vegetables grown with organic fertilizations," Acta Horticulture, vol. 627, pp. 25-33, 2005.

[17] H. S. Hammad, A. A. M. Al-Mandalawi, and G. J. Hamdi, "Effect of manure on growth and yield of broccoli," International Journal of Vegetable Science, vol. 25, no. 4, pp. 400-406, 2019.

[18] M. M. Islam, A. J. M. S. Karim, M. Jahiruddin et al., "Effects of organic manure and chemical fertilizers on crops in the radish-stem amaranth-Indian spinach cropping pattern in homestead area," Australian Journal of Crop Science, vol. 5, pp. 1370-1378, 2011.

[19] M. O. Ariyo, J. A. Akoun, O. C. Aliyo, and C. Emeghara, "Effect of organic manures and spacing on the yield of Amaranthus cruentus," in Proceedings of the Conference on Organic Agriculture for Health, Wealth and Environmental Conservation, Federal University of Technology, Owerri, Nigeria, V. C. Umeh and A. Fagbayide, Eds., pp. 63-67, 2009.

[20] L. M. R. Gonzales, R. A. Caralde, and M. Aban, "Response of Pechay (Brassica napus L.) to different levels of compost fertilizer," International Journal of Scientific and Research Publications, vol. 5, p. 2, 2015. 